\title{
Profitability and Dividend Policy Affects Firm Value in The Infrastructure, Utility and Transportation Sector
}

\author{
Venina Cindy Kusumawati ${ }^{1 *}$, Harijono Harijono ${ }^{2}$ \\ 1,2 Faculty of Economics and Business, Satya Wacana Christian University, Salatiga, Indonesia
}

\section{A R T I C L E I N F O}

Article history:

Received 09 November 2020

Received in revised form

25 November 2020

Accepted 17 December 2020

Available online 25 February

2021

Keywords:

Profitability, Dividend Policy, Firm Value

\begin{abstract}
A B S T R A C T
Previous study uses six bank companies which are listed in Indonesia Stock Exchange as the object and using ROE in calculating profitability. The researcher suggests to using a variable other than ROE to calculate profitability, increasing the number of samples and using other sector such as infrastructure, utility and transportation sector as the object. Hence, this study aims to prove the effect of profitability and dividend policy on firm value in the infrastructure, utility and transportation sector. The data were obtained from the financial statements of company listed on Indonesian Stock Exchange. Firm value as a dependent variable were measured by price to book value, profitability and dividend policy as independent variable were measured by return on assets and dividend payout ratio. They were analyzed using Multiple Linear Regression with classical assumption test in Statistical Package for the Social Sciences program. The results indicated that profitability and dividend policy can affect firm value simultaneously, profitability has no effect on firm value while dividend policy can positively affect firm value.
\end{abstract}

Copyright (C) Universitas Pendidikan Ganesha. All rights reserved.

\section{Introduction}

Every company has the same goal, which is to gain maximum possible profit. In addition, the company's goal is also to increase firm value. High value of the company reflects high share prices. A high share price means high prosperity for the shareholders of the company. Firm value can be an indicator for investors to assess a company. High corporate value reflects good financial position and abundant resources. If the firm's value is high, investors will be interested in investing in the company (Dhani \& Utama, 2017; Rudangga \& Sudiarta, 2016).

There are several factors that influence firm value. In this study, there are two variables used that can influence firm value, namely profitability and dividend policy. The higher the profitability will have an impact on increasing firm value. This reflects that the company's capability is increasing in obtaining profits and distributing dividends to shareholders (Suwardika \& Mustanda, 2017). Investors often consider dividend policy as a sign in giving value to the company because it can affect the value of the firm. Investors will prefer companies that are able to provide certainty of return on investment in the form of dividends. The higher the dividends distributed, the company is considered profitable and has good performance (Putra \& Lestari, 2016).

Research on profitability has had mixed results. First, previous research found that profitability has a positive effect on firm value (Noviani et al., 2019; Rudangga \& Sudiarta, 2016; Kadim \& Sunardi, 2019). The results of this study contradict research from Ratih \& Damayanthi (2016) who found that profitability cannot affect firm value. In addition, Wulandari \& Wiksuana (2017) found that profitability has a negative effect on firm value. Research on dividend policy has also had mixed results. Research conducted by Prastuti \& Sudiartha (2016) and Putra \& Lestari (2016) found that dividend policy has a positive effect on firm value. This is in contrast to Anita \& Yulianto (2016), who found that dividend policy has no effect on firm value. Research that has been conducted by Martha et al. (2018) still has its limitations. Increasing the number of companies and using sectors other than banking, such as infrastructure, utilities and transportation as research objects. The researchers also suggest using a variable measuring tool other than ROE in calculating profitability. Therefore, another research was 
carried out using ROA as a measure of profitability. Then the dividend policy is proxied by the dividend payout ratio and the firm value is proxied by the price to book value. Furthermore, Martha et al. (2018) suggest increasing the number of samples and using companies in the infrastructure, utilities and transportation sectors as research objects.

This study aims to analyze the effect of profitability and dividend policy on firm value. This study can add new literature on the effect of profitability and dividend policy on firm value. In addition, it is expected to become a reference for scientific development. The benefit of this research is that it is able to become a consideration for a company in creating firm value.

\section{Methods}

In this study, the type of data used is quantitative secondary data. The required data was obtained from the Indonesia Stock Exchange (IDX) website in 2016-2019. This study used one dependent variable, namely firm value, two independent variables, namely profitability and dividend policy. The population studied was the infrastructure, utility and transportation sector companies listed in the IDX (Indonesia Stock Exchange) in the 2016-2019 period. Purposive sampling method was used to obtain samples. Purposive sampling method is sampling using certain criterias. These criteria are as follows: (1) Infrastructure, utility and transportation sector service companies listed in the IDX during the 2016-2019 period; (2) Infrastructure, utility and transportation sector companies that have complete financial reports in the 2016-2019 period; (3) Infrastructure, utility and transportation sector companies that distribute dividends in the 2016-2019 period. The sample selection process according to the applied criteria is presented in Table 1.

Table 1. Total Population and Sample

\begin{tabular}{lc}
\hline \multicolumn{1}{c}{ Description } & Total \\
\hline Infrastructure, utility and transportation sector companies listed in the IDX in 2016-2019 & 77 \\
Infrastructure, utility and transportation sector companies that do not provide financial & 25 \\
reports for the 2016-2019 period & 42 \\
Infrastructure, utility and transportation sector companies that did not distribute dividends \\
in the 2016-2019 period & 10 \\
The number of companies used as samples & 40 \\
Amount of observation data (10 companies x 4 years of observation) &
\end{tabular}

The dependent variable used in this study was firm value. firm value is proxied in Price to Book Value. Price to Book Value (PBV) is giving a price of the value of a share based on the size of the market. The higher the PBV ratio, the higher the company's performance in the eyes of investors with the funds that have been invested in the company.

Connected to this, the level of trust in the company's prospects is high, the attractiveness of investors is high so that demand increases and share prices increase (Sunardi \& Febrianti, 2020). The calculation of firm value is formulated as follows:

$$
P B V=\frac{\text { market price per stock }}{\text { book value per share }}
$$

The independent variables used in this study were profitability and dividend policy. Profitability is proxied by Return on Assets (ROA). Return on Assets describes the company's ability to generate profits with the assets owned by the company (Jaya, 2020). The calculation of the company's profitability is formulated as follows:

$$
\text { ROA }=\frac{\text { net income after tax }}{\text { total asset }} x 100 \%
$$

The second independent variable is dividend policy. Dividend policy is proxied in the Dividend Payout Ratio (DPR). DPR is influenced by the company's net income. The greater the profit obtained, the greater the company's ability to distribute dividends (Paulus, Rushadiyati, \& Rumahorbo, 2020). The DPR measures the amount of net profit per share paid in the form of dividends. The calculation of the Dividend Payout Ratio (DPR) is formulated as follows:

$$
D P R=\frac{\text { divident per share }}{\text { earning per share }} \times 100 \%
$$


This study used multiple regression analysis techniques for the direction of influence and impact of the independent variable on the dependent variable. Prior to performing multiple regression tests, it was necessary to test the classical assumption. The steps taken for the classical assumption test were normality test, multicollinearity test, heteroscedasticity test, and autocorrelation (Marfuah \& Nurlaela, 2017; Sriningsih, Hatidja, \& Prang, 2018; Ayuwardani \& Isroah, 2018; Almunawwaroh \& Marliana, 2018). Thus the regression model formulated in this study is:

$$
Y=\alpha+\beta 1 X 1+\beta 2 X 2+e
$$

Notes:

Y : Firm value

$\alpha \quad$ : Constant number

$\beta \quad$ : Standardized coefficient beta

$\mathrm{X}_{1} \quad$ : Profitability

$\mathrm{X}_{2} \quad$ : Dividend policy

After the classical assumption test was fulfilled, the next step was to test the hypothesis by performing two tests, the $\mathrm{F}$ test and the $\mathrm{t}$ test. The $\mathrm{F}$ test was used to see the effect of the independent variables simultaneously or together towards the dependent variable (Languju, Mangantar, \& Tasik, 2016). Whereas the $t$ test was used to determine the effect of each independent variable on the dependent variable significantly (Bulan, 2016).

Furthermore, the coefficient of determination (R-Square) was tested. This test was used to see how much the independent variable was able to explain the dependent variable. The R-square value that is close to number one means that the independent variable is able to provide information on the dependent variable (Triyono, Raharjo, \& Arifati, 2015).

\section{Results and Discussions}

\section{Descriptive Analysis Results}

There were 77 companies in the infrastructure, utility and transportation sectors listed on the Indonesia Stock Exchange (IDX) in 2016-2019 and there were 10 companies that met the criteria. These companies shown in Table 2.

Table 2. List of Companies

\begin{tabular}{rcl}
\hline No & Company Code & \multicolumn{1}{c}{ Company Name } \\
\hline 1. & BIRD & Blue Bird \\
2. & SMDR & Samudera Indonesia \\
3. & SOCI & Soechi Lines \\
4. & TPMA & Trans Power Marine \\
5. & PGAS & Perusahaan Gas Negara \\
6. & RAJA & Rukun Raharja \\
7. & JSMR & Jasa Marga \\
8. & TLKM & Telekomunikasi Indonesia \\
9. & TBIG & Tower Bersama Infrastructure \\
10. & TOWR & Sarana Menara Nusantara \\
\hline
\end{tabular}

Based on the results of the descriptive statistical analysis in Table 3, the proxied profitability of ROA has a minimum profitability value of $-7.42 \%$ and a maximum value of $16.50 \%$. The average profitability value of $6.0825 \%$ indicates that companies in the infrastructure, utility and transportation sectors listed on the IDX have an average profitability of $6.0825 \%$.

The minimum dividend policy value is $-0.10 \%$ and the maximum dividend policy value is $107.16 \%$. The average dividend policy value is $42.3362 \%$, which means that the average dividend policy of companies in the infrastructure, utility and transportation sectors listed on the IDX is $42.3362 \%$. The deviation of the dividend policy value from the average value is $28.58440 \%$.

The firm value range is between 0.14 times at Ltd. Samudera Indonesia Plc for the 2019 period to 14.05 times at Ltd. Tower Bersama Infrastructure Plc for the 2016 period. The average value of the firm value is 2.1850 times, which means that the average value of companies in the infrastructure, utility and 
transportation sector companies listed on the Indonesia Stock Exchange is 2.1850 times. The standard deviation value of the firm shows the deviation in value from the average value, which is 2.68587 times.

Table 3. Descriptive Statistics Results

\begin{tabular}{|c|c|c|c|c|}
\hline & Min & Max & Mean & Std. Deviation \\
\hline Profitability (\%) & -7.42 & 16.50 & 6.0825 & 5.03946 \\
\hline Dividend Policy (\%) & -0.10 & 107.16 & 42.3362 & 28.58440 \\
\hline Firm value (multiple) & 0.14 & 14.05 & 2.1850 & 2.68587 \\
\hline
\end{tabular}

\section{The Classical Assumption Test}

Normality Test Results

A good regression model is data that is distributed normally. Data that is normally distributed can be seen with a significance value $>0.05$ in the Kolmogorov-Smirnov.

Table 4. Normality Test Results

\begin{tabular}{lr}
\hline & Kolmogorov-Smirnov \\
\hline Profitability & 0.077 \\
Dividend Policy & 0.200 \\
Firm Value & 0.117 \\
\hline
\end{tabular}

In Table 4, the results of the normality test above show that the Kolmogorov-Smirnov probability value for profitability is 0.077 , dividend policy is 0.200 and the firm value is 0.117 . This figure is $>0.05$, so it can be concluded that the data has been normally distributed.

\section{Multicollinearity Test Results}

Multicollinearity test was used to see the correlation between independent variables. In this test it is said the multicollinearity test passed if the value of $\mathrm{VIF}<10$.

Table 5. Multicollinearity Test Results

\begin{tabular}{lr}
\hline & VIF \\
\hline Profitability & 1.137 \\
Dividend Policy & 1.137 \\
\hline
\end{tabular}

Based on Table 5 above, it shows that the VIF value on profitability and dividend policy is 1.137. This figure is less than the VIF value of 10 , so it can be concluded that it passed the multicollinearity test.

\section{Heteroscedasticity Test Results}

Heteroscedasticity test was also one of the requirements before the regression test was carried out. This test was done to see variants with different residuals. Based on Table 6, it shows that there are no symptoms of heteroscedasticity. This is proven by a significance value of more than 0,05 .

Table 6. Heteroscedasticity Test Results

\begin{tabular}{lr}
\hline & Sig \\
\hline Profitability & 0.596 \\
Dividend Policy & 0.154 \\
\hline
\end{tabular}

\section{Autocorrelation Test Results}

The autocorrelation test was performed using the Durbin-Watson test. In Table 7, after the autocorrelation test is carried out, the Durbin-Watson value is 1.737. From the Durbin-Watson table, with the number of independent variables as much as $2(\mathrm{k}=2)$, and the number of samples of 40 , the dl value is 1.3908 , du is 1.6, 4-du is 2.34, and 4- $\mathrm{dl}$ is 2.6092. From these numbers, it can be concluded that there is no autocorrelation. 
Table 7. Autocorrelation Test Results

\begin{tabular}{crrrrr}
\hline Dl & Du & DW & 4-Du & 4-Dl & Conclusion \\
\hline 1.3908 & 1.6 & 1.737 & 2.4 & 2.6092 & There is no autocorrelation \\
\hline
\end{tabular}

\section{Multiple Linear Regression Test Results}

Multiple linear regression with two independent variables and one dependent variable was used in this study. This test aims to see the effect of the independent variable on the dependent variable.

Table 8. Multiple Linear Regression Test Results

\begin{tabular}{lcrr}
\hline & \multicolumn{2}{c}{ Unstandardized Coefficients } \\
\cline { 2 - 4 } & B & \multicolumn{2}{c}{ Std. Error } \\
\hline (Constant) & 0.257 & 0.765 \\
Profitability & 0.079 & 0.084 \\
Dividend Policy & 0.034 & 0.015 \\
\hline
\end{tabular}

$$
Y=0.257+0.079 X 1+0.034 X 2+e
$$

Based on the regression equation model above, it can be concluded that the constant value of 0.0257 indicates that if the profitability variable and dividend policy are 0 , then the firm value variable is 0.00257 units. The regression coefficient value of the profitability variable is 0.079 , indicating that if the profitability variable increases by one unit, the firm value variable will increase by 0.079 , assuming the other variables are constant. The regression coefficient value of the dividend policy variable is 0.034 , indicating that if the dividend policy variable increases by one unit, the firm value variable will increase by 0.034 , assuming the other variables are constant.

\section{Hypothesis Test Results F Test}

The F test was used for hypothesis testing. The F test is used to see the effect of all independent variables together towards the dependent variable. Based on the results of the F test in Table 9, the pvalue is 0.019 . This means that the variables of profitability and dividend policy together or simultaneously have an effect on firm value.

Table 9. F Test Results

\begin{tabular}{lrr}
\hline & p-value & \\
\hline Regression & 0.019 \\
\hline
\end{tabular}

\section{The T-Test}

The $t$ test aims to test the effect of each independent variable on the dependent variable. $p$-value is used to see possible errors that occur in the hypothesis testing. If the p-value is less than 0.05 then the hypothesis is accepted.

Table 10. $\mathrm{T}$ test results

\begin{tabular}{lr}
\hline & p-value \\
\hline Profitability $\rightarrow$ Firm Value & 0.350 \\
Dividend Policy $\rightarrow$ Firm Value & 0.027 \\
\hline
\end{tabular}

\section{R-Squared Test}

The R-Squared test or the coefficient of determination test was used to see the magnitude of the effect of the independent variable on the dependent variable. The R-Squared test result in Table 11 is the $\mathrm{R}$ Square value of 0.192 . This means that the ability of the independent variable in explaining the dependent variable is $19.2 \%$ and the remaining $80.8 \%$ is explained by other factors. 
Table 11. R-Squared Test Results

\begin{tabular}{ccc}
\hline $\mathbf{R}$ & R Square & Adjusted R Square \\
\hline 0.438 & 0.192 & 0.148 \\
\hline
\end{tabular}

\section{Discussion \\ Profitability has a positive effect on firm value}

Based on the results of research and data analysis, the p-value is 0.350 . This value exceeds the standard p-value of 0.05 . This shows that profitability has no effect on firm value. The profitability of a company depends on the level of sales. The profitability of a company depends on the level of sales. The fluctuating sales value of the company will lead to uncertain profitability as well. The high profit earned by the company does not have an impact on firm value. Rosada \& Idayati (2017) found that investors' general view of the welfare from the investment results invested in a company is not from profit but from the stock market price. Thus profitability cannot be used as a reference for assessing a company. These results are in line with the research by Pratiwi \& Mertha (2017), Robiyanto et al. (2020), and Wicaksono \& Mispiyanti (2020) which prove that there is no effect of profitability on firm value.

\section{Dividend policy has a positive effect on firm value}

Based on the results of research and data analysis, the p-value is 0.027 . This value is less than the standard p-value of 0.05 . This means that the second hypothesis is accepted that dividend policy has a positive effect on firm value. The amount of profit obtained by investors depends on the dividend policy of each company. The results of this study are in line with the bird in the hand theory, where the high dividends distributed by the company will have an impact on the high value of the company. In addition, investors also prefer companies that distribute dividends as a result of their investments. The higher the level of the DPR, the higher the firm value. This result is in accordance with the signal theory which states that a company with a high DPR level will be a signal for investors and the company will gain high trust from investors. These results are consistent with research conducted by Utami \& Darmayanti (2018) and Musabbihan \& Purnawati (2018) which found that there is an effect of dividend policy on firm value

\section{Conclusion}

This research was conducted to prove the influence of profitability and dividend policy on firm value, the effect of profitability and dividend policy simultaneously on firm value. Based on the results of the analysis it can be concluded as follows: (1) profitability and dividend policy together can affect firm value, (2) profitability has no effect on firm value, (3) dividend policy can positively affect firm value. The limitation of this study is that this study used companies in the infrastructure, utility and transportation sectors as research objects. Many companies in this sector do not distribute dividends because the companies suffered losses. So that of the 77 companies in the infrastructure, utility and transportation sectors, only 10 companies passed the criteria to be used in the research. Suggestion for further research is to use the object of research with companies in sectors other than the infrastructure, utilities and transportation sectors that distribute dividends each year.

\section{References}

Almunawwaroh, M., \& Marliana, R. (2018). Pengaruh CAR, NPF, dan FDR Terhadap Profitabilitas Bank Syariah di Indonesia. Amwaluna Jurnal Ekonomi dan Keuangan Syariah, 2(1), 1-18. https://ejournal.unisba.ac.id/index.php/amwaluna/article/view/3156/2149.

Anita, A., \& Yulianto, A. (2016). Pengaruh Kepemilikan Manajerial dan Kebijakan Dividen Terhadap Nilai $\begin{array}{llll}\text { Perusahaan. } & \text { Management }\end{array}$ https://journal.unnes.ac.id/sju/index.php/maj/article/view/8116.

Ayuwardani, R. P., \& Isroah. (2018). Pengaruh Informasi Keuangan dan Non Keuangan Terhadap Underpricing Harga Saham Pada Perusahaan Yang Melakukan Initial Public Offering (Studi Empiris Perusahaan Go Public Yang Terdaftar Di Bursa Efek Indonesia Tahun 2011-2015). Jurnal Nominal Barometer Riset Akuntansi dan Manajemen, 7(1), 143-158. https://journal.uny.ac.id/index.php/nominal/article/view/19781/10809.

Bulan, T. P. L. (2016). Pengaruh Labelisasi Halal Terhadap Keputusan Pembelian Sosis di Kuala Simpang Kabupaten Aceh Tamiang. Jurnal Manajemen dan Keuangan, 5(1), 430-439. 
https://ejurnalunsam.id/index.php/jmk/article/view/49.

Dhani, I. P., \& Utama, A. . G. S. (2017). Pengaruh Pertumbuhan Perusahaan, Struktur Modal, dan Profitabilitas Terhadap Nilai Perusahaan. Jurnal Riset Akuntansi dan Bisnis Airlangga, 2(1), 135148. http://jraba.org/journal/index.php/jraba/article/view/28/14

Jaya, S. (2020). Pengaruh Ukuran Perusahaan (Firm Size) dan Profitabilitas (ROA) Terhadap Nilai Perusahaan (Firm Value) Pada Perusahaan Sub Sektor Property dan Real Estate di Bursa Efek Indonesia (BEI). Jurnal Manajemen Motivasi, 16(1), 38-44. http://dx.doi.org/10.29406/jmm.v16i1.2136.

Kadim, A., \& Sunardi, N. (2019). Pengaruh Profitabilitas, Ukuran Perusahaan Terhadap Leverage Implikasi Terhadap Nilai Perusahaan Cosmetics and Household yang Terdaftar di Bursa Efek Indonesia. Jurnal Sekuritas, 3(1), 22-32. http://dx.doi.org/10.32493/skt.v3i1.3270.

Languju, O., Mangantar, M., \& Tasik, H. H. D. (2016). Pengaruh Return On Equity, Ukuran Perusahaan, Price Earning Ratio dan Struktur Modal Terhadap Nilai Perusahaan Property dan Real Estate Terdaftar di Bursa Efek Indonesia. Jurnal Berkala Ilmiah Efisiensi, 16(02), 387-398. https://ejournal.unsrat.ac.id/index.php/jbie/article/view/12530/12102.

Marfuah, S. A., \& Nurlaela, S. (2017). Pengaruh Ukuran Perusahaan, Pertumbuhan Asset, Profitabilitas dan Pertumbuhan Penjualan Terhadap Struktur Modal Perusahaan Cosmetics and Household di Bursa Efek Indonesia. Jurnal Akuntansi dan Pajak, 18(1), 16-30. http://jurnal.stieaas.ac.id/index.php/jap/article/view/81/71.

Martha, L., Sogiroh, N. U., Magdalena, M., Susanti, F., \& Syafitri, Y. (2018). Profitabilitas dan Kebijakan Dividen Terhadap Nilai Perusahaan. Jurnal Benefita, 3(2), 227-238. http://ejournal.lldikti10.id/index.php/benefita/article/view/3493/0.

Musabbihan, N. A., \& Purnawati, N. K. (2018). Pengaruh Profitabilitas dan Kebijakan Dividen Terhadap Nilai Perusahaan Dengan Struktur Modal Sebagai Pemediasi. E-Jurnal Manajemen Unud, 7(4), 1979-2009. https://doi.org/10.24843/EJMUNUD.2018.v07.i04.p10.

Noviani, A. V., Atahau, A. D. Ra., \& Robiyanto, R. (2019). Struktur Modal, Profitabilitas dan Nilai Perusahaan: Efek Moderasi Good Corporate Governance. Jurnal Ekonomi dan Bisnis, 22(2), 391415. https://doi.org/10.24914/jeb.v22i2.2601.

Paulus, J., Rushadiyati, \& Rumahorbo. (2020). Pengaruh Free Cash Flow dan Profitabilitas Terhadap Kebijakan Dividen (Divident Payout Ratio) Pada PT Gudang Garam Tbk tahun 2010-2018. Jurnal Administrasi dan Manajemen, 10(1), 85-98. http://ejournal.urindo.ac.id/index.php/administrasimanajemen/article/view/872/686.

Prastuti, N. K. R., \& Sudiartha, I. G. M. (2016). Pengaruh Struktur Modal, Kebijakan Dividen dan Ukuran Perusahaan Terhadap Nilai Perusahaan Pada Perusahaan Manufaktur. E-Jurnal Manajemen Unud, 5(3), 1572-1598. https://ojs.unud.ac.id/index.php/Manajemen/article/view/16540.

Pratiwi, N. P. D., \& Mertha, M. (2017). Pengaruh Kebijakan Hutang dan Profitabilitas Pada Nilai Perusahaan Dengan Kebijakan Dividen Sebagai Variabel Pemoderasi. E-Jurnal Akuntansi Universitas Udayana, 20(2), 1446-14775. https://ocs.unud.ac.id/index.php/Akuntansi/article/view/29597.

Putra, A. N. D. A., \& Lestari, P. V. (2016). Pengaruh Kebijakan Dividen, Likuiditas, Profitabilitas dan Ukuran Perusahaan Terhadap Nilai Perusahaan. E-Jurnal Manajemen Unud, 5(7), 4044-4070. https://ojs.unud.ac.id/index.php/Manajemen/article/view/20373.

Ratih, I. D. A., \& Damayanthi, I. G. A. E. (2016). Kepemilikan Manajerial dan Profitabilitas Pada Nilai Perusahaan Dengan Pengungkapan Tanggungjawab Sosial Sebagai Variabel Pemoderasi. E-Jurnal $\begin{array}{llll}\text { Akuntansi Universitas } \quad \text { Udayana, 14(2), } & \text { 1510-1538. }\end{array}$ https://ojs.unud.ac.id/index.php/Akuntansi/article/view/16175.

Robiyanto, Nafiah, I., Harijono, \& Inggarwati, K. (2020). Pengaruh Profitabilitas Terhadap Nilai Perusahaan Perhotelan dan Pariwisata Melalui Struktur Modal Sebagai Variabel Intervening. Jurnal Ilmiah Bisnis dan Ekonomi Asia, 14(1), 46-57. https://doi.org/10.32812/jibeka.v14i1.153.

Rosada, F. L. A., \& Idayati, F. (2017). Pengaruh Profitabilitas Terhadap Nilai Perusahaan Otomotif di Bursa Efek Indonesia. Jurnal IImu dan Riset Akuntansi, 6(1), 255-274. http://jurnalmahasiswa.stiesia.ac.id/index.php/jira/article/view/757. 
Rudangga, I. G. N. G., \& Sudiarta, G. M. (2016). Pengaruh Ukuran Perusahaan, Leverage dan Profitabilitas Terhadap Nilai Perusahaan. E-Jurnal Manajemen Unud, 5(7), 4394-4422. https://ojs.unud.ac.id/index.php/Manajemen/article/view/21920.

Sriningsih, M., Hatidja, D., \& Prang, J. D. (2018). Penanganan Multikolinearitas Dengan Menggunakan Analisis Regresi Komponen Utama Pada Kasus Impor Beras di Provinsi Sulut. Jurnal Ilmiah Sains, 18(1), 18-24. https://ejournal.unsrat.ac.id/index.php/JIS/article/view/19396/19069.

Sunardi, N., \& Febrianti, F. (2020). Likuiditas dan Kebijakan Hutang Pengaruhnya terhadap Kinerja Perusahaan dan Dampaknya Terhadap Nilai Perusahaan pada Industri Sektor Telekomunikasi di Indonesia. Jurnal Ilmiah Manajemen Forkamma, 3(3), 269-282. http://www.openjournal.unpam.ac.id/index.php/FRKM/article/view/6206/4144.

Suwardika, I. N. A., \& Mustanda, I. K. (2017). Pengaruh Leverage, Ukuran Perusahaan, Pertumbuhan Perusahaan, dan Profitabilitas Terhadap Nilai Perusahaan Pada Perusahaan Properti. E-Jurnal $\begin{array}{lll}\text { Manajemen } \quad \text { Unud, } & \text { 6(3), }\end{array}$ https://ojs.unud.ac.id/index.php/Manajemen/article/view/27276.

Triyono, T., Raharjo, K., \& Arifati, R. (2015). Pengaruh Kebijakan Dividen, Struktur Kepemilikan, Kebijakan Hutang, Profitabilitas dan Ukuran Perusahaan Terhadap Nilai Perusahaan Pada Perusahaan Manufaktur di Bursa Efek Indonesia. Jurnal Ilmiah Mahasiswa Akuntansi, 1(1), 1-13. http://jurnal.unpand.ac.id/index.php/AKS/article/view/328/324.

Utami, A. P. S., \& Darmayanti, N. P. A. (2018). Pengaruh Keputusan Investasi, Keputusan Pendanaan dan Kebijakan Dividen Terhadap Nilai Perusahaan Food and Beverages. E-Jurnal Manajemen Unud, 7(10), 5719-5747. https://doi.org/10.24843/EJMUNUD.2018.v07.i10.p18.

Wicaksono, R., \& Mispiyanti. (2020). Analisis Pengaruh Profitabilitas dan Kebijakan Dividen Terhadap Nilai Perusahaan dengan Struktur Modal sebagai Variabel Mediasi. Owner: Riset dan Jurnal Akuntansi, 4(2), 396-411. https://doi.org/10.33395/owner.v4i2.237.

Wulandari, N. M. I., \& Wiksuana, I. G. B. (2017). Peranan Corporate Social Responsibility Dalam Memoderasi Pengaruh Profitabilitas, Leverage dan Ukuran Perusahaan Terhadap Nilai Perusahaan. E-Jurnal Manajemen Unud, 6(3), 1278-1311. https://ojs.unud.ac.id/index.php/Manajemen/article/view/27466. 